\title{
Pengembangan Interaksi Sosial Anak Autis melalui Terapi Applied Behavior Analysis
}

\author{
Ai Siti ${ }^{1 *}$, Elly Marlina ${ }^{2}, \&$ Dudy Imanuddin Effendy ${ }^{3}$ \\ 123Jurusan Bimbingan Konseling Islam, Fakultas Dakwah dan Komunikasi, Universitas Islam \\ Negeri Sunan Gunung Djati, Bandung \\ *Email : asaisiti19@gmail.com
}

\begin{abstract}
ABSTRAK
Penelitian ini bertujuan untuk mendeskripsikan kondisi awal kemampuan interaksi sosial anak autis, proses pelaksanaan dan hasil dari bimbingan dengan metode terapi Applied Behavior Analysis. Metode penelitian yang digunakan yaitu deskriptif kualitatif. Hasil penelitian menunjukkan: kondisi awal kemampuan interaksi sosial anak autis masih belum memiliki kontak mata yang fokus dan bahasa verbal yang bagus. Proses pelaksanaan bimbingan kepada anak autis usia SDLB dilakukan oleh terapis; Bimbingan kepada anak autis usia kelas vokasional oleh konselor;Bbimbingan oleh semua pegawai SLB Autisma Bunda Bening Selakshahati selama 24 jam penuh. Hasil bimbingan menunjukkan bahwa anak autis mampu memiliki kontak mata yang fokus dan bahasa verbal yang bagus.
\end{abstract}

Kata Kunci: Bimbingan; Metode Terapi Applied Behavior Analysis; Interaksi Sosial; Anak Autis.

\section{ABSTRACT}

This study aims to describe the initial conditions of social interaction skills of children with autism, the implementation process, and the results of guidance using the Applied Behavior Analysis method. The research method used is descriptive qualitative. The results showed that: the initial condition of the social interaction ability of children with autism still did not have focused eye contact and acceptable verbal language. Therapists carry out implementing guidance for children with autism at SDLB age; Guidance for children with autism in a vocational class by counselors; Guidance by all employees of SLB Autism Bunda Bening Selakshabati for 24 hours straight. The guidance results show that children with autism can have focused on eye contact and acceptable verbal language.

Keywords: Guidance; Applied Behavior Analysis Therapy Method; Social interactions; Autistic Child. 
A, Siti., E, Marlina., D, EI, Effendy.

\section{PENDAHULUAN}

Anak Berkebutuhan Khusus (ABK) adalah anak yang harus diberikan penanganan khusus untuk mengatasi kelainan yang dimilikinya. (Desiningrum, 2016: 1). Salah satu golongan yang termasuk ke dalam anak berkebutuhan khusus, yaitu anak autis. Sebutan tersebut diperuntukan bagi anak yang mengalami gangguan perkembangan yang kompleks, berat dan menetap. Anak cenderung tidak mampu mengekspresikan keinginannya, selalu melakukan perbuatan yang berulang-ulang, tidak mampu melakukan kontak mata, menunjukkan perilaku yang tidak hangat, sering menarik diri dari lingkungan dan tidak mampu berkomunikasi dengan orang lain.

Sebagian besar masyarakat menganggap anak autis sebagai anak yang mengalami gangguan jiwa dan dapat menjadi beban bagi keluarganya. Padahal anak autis pun tentu memiliki kelebihan, hak dan kewajiban yang serupa seperti orang normal pada umumnya. Sebab, tidak semata-mata Allah menciptakan sesuatu tanpa manfaatnya dan Allah tidak memberikan sesuatu tanpa ada hikmahnya. Oleh sebab itu, dibutuhkan orang yang paham terhadap kebutuhan dari anak autis supaya dapat diberikan penanganan yang tepat untuk membantu perkembangannya. Namun, dalam hal ini kebanyakan orang tua tidak tahu dan tidak mampu untuk melakukannya. Sehingga, para orang tua banyak yang mempercayakan anaknya pada SLB (Sekolah Luar Biasa).

Dilansir dari berita yang disiarkan website Kementrian Pemberdayaan Perempuan dan Perlindungan Anak (Kemenpppa) hari senin tanggal 02 April 2018, disebutkan bahwa dengan jumlah penduduk Indonesia sekitar 237,5 juta dengan laju pertumbuhan penduduk 1,14\% (BPS, 2010), maka diperkirakan penyandang ASD (Autism Spectrum Disorder) di Indonesia yaitu 2,4 juta orang dengan pertambahan penyandang baru 500 orang/tahun. (Kemenpppa, kemenpppa.go.id, akses 02 April 2018).

Pertambahan anak autis di Indonesia semakin tinggi tetapi sekolah atau tempat terapi yang menangani anak autis masih terbatas. Akan tetapi sekolah atau tempat terapi memberikan pendidikan dan bimbingan yang optimal untuk memfasilitasi dan memaksimalkan potensi yang dimiliki anak autis supaya dapat berkembang ke arah yang lebih baik. Salah satu Sekolah Luar Biasa yang berada di Kota Bandung yaitu SLB Autisma Bunda Bening Selakshahati, membuka program pendidikan dan bimbingan dengan konsep asrama untuk anak autis.

Adapun untuk penanganannya, menurut Kingley (2006: 8) metode Applied Behavior Analysis merupakan metode yang representatif untuk digunakan. Hal ini disebabkan oleh sifatnya yang sistematis dan terarah. Sebuah metode untuk membantu anak autis dalam mengembangkan kemampuan interaksi sosialnya yaitu dengan memberikan bimbingan dengan metode terapi Applied Behavior Analysis. Usaha untuk membantu anak autis mengembangkan kemampuan 
Pengembangan Interaksi Sosial Anak Autis melalui Terapi Applied Behavior Analysis interaksi sosial ini merupakan upaya untuk mengubah keadaan seseorang yang merupakan implementasi dari firman Allah yang termaktub dalam QS. Ar-Ra'd ayat 11 :

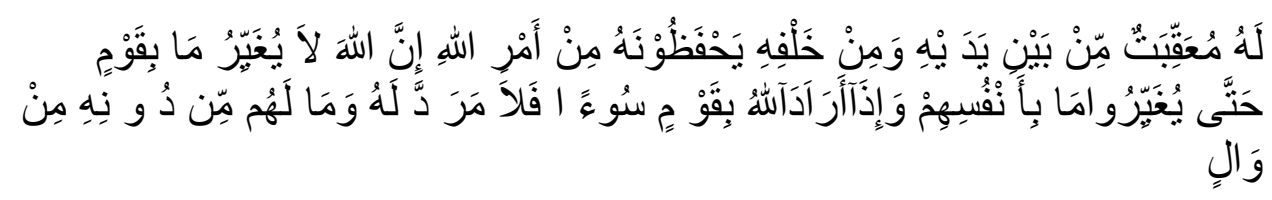

Artinya:

Bagi manusia ada malaikat-malaikat yang selalu mengikutinya bergiliran, di muka dan di belakangnya, mereka menjaganya atas perintah Allah. Sesungguhnya Allah tidak merubah keadaan sesuatu kaum sehingga mereka merubah keadaan yang ada pada diri mereka sendiri. Dan apabila Allah menghendaki keburukan terhadap sesuatu kaum, maka tak ada yang dapat menolaknya; dan sekali-kali tak ada pelindung bagi mereka selain Dia." (Umar, Sayahafiz.com, akses 2014).

Sesuai dengan hasil penelitian sebelumnya mengenai "Perilaku Anak Berkebutuhan Khusus Gangguan Autisme di SLB Negeri Semarang” yang ditulis oleh Diah Widiastuti bahwa gangguan interaksi sosial yang sering dijumpai pada seseorang yang menderita gangguan autisme biasanya menghindari kontak mata, anak tidak merespon saat dipanggil, anak menolak untuk berinteraksi dengan orang lain dan cenderung menghindar karena lebih tertarik dengan obyek. Selanjutnya hasil penelitian lainnya adalah Penanganan Anak Autis dalam Interaksi Sosial yang ditulis oleh Asrizal bahwa penanganan anak autis mencakup dua yaitu penanganan dini bisa dilakukan intervensi dini, terapi ABA, dan kelompok khusus sedangkan penanganan terpadu bagi anak autis menjadi sebuah keharusan apabila penanganan dini tidak berhasil secara objektif.

Salah satu sekolah luar biasa yang memberikan bimbingan dengan metode terapi Applied Behavior Analysis kepada anak dengan kelainan autis yaitu Sekolah Luar Biasa Autisma Bunda Bening Selakshahati yang terletak di Kampung Cibirubeet Hilir RT 05 RW 13, Desa Cileunyi Wetan, Kabupaten Bandung. Setelah dilakukan observasi awal, dapat ditemukan bahwa anak-anak autis yang ada di Sekolah Luar Biasa Autisma Bunda Bening Selakshahati lebih berkembang dalam kemampuan interaksi sosialnya dibandingkan dengan anak autis pada umumnya. Hal ini dapat dilihat dari sikap anak autis Sekolah Luar Biasa Autisma Bunda Bening Selakshahati yang mampu melakukan kontak mata, menyapa dan bersalaman (meskipun dengan mimik wajah yang acuh) dengan peneliti saat melakukan observasi mata kuliah Bimbingan Konseling Anak Berkebutuhan Khusus (ABK). Oleh sebab itu, peneliti ingin melakukan penelitian untuk mengetahui kondisi awal kemampuan interaksi sosial anak autis, proses pelaksanaan bimbingan dan hasil dari bimbingan dengan metode terapi Applied Behavior Analysis di Sekolah Luar Biasa Autisma Bunda Bening Selakshahati. 
Alasan lain yang membuat peneliti tertarik untuk meneliti di sini disebabkan oleh adanya program asrama bagi anak autis yang bersekolah di termapt tersebut.

Dengan diadakannya penelitian dari permasalahan yang dipaparkan di atas tentang pentingnya tumbuh kembang anak autisme, maka peneliti tertarik untuk mendalami lebih jauh tentang bagaimanan pelaksanaan bimbingan dengan menggunakan metode terapi Applied Behavior Analysis di Sekolah Luar Biasa Autisma Bunda Bening Selakshahati yang menerapkan pola hidup asrama. Penelitian ini diharapkan dapat menambah pemahaman orang tua serta calon konselor Islam dalam membantu anak dengan kelainan autis supaya dapat lebih berkembang dalam menjalani kehidupannya dan lebih jauhnya dapat mengenalkan syariat Islam pada mereka.

Fokus penelitian bertujuan untuk menganalisis kondisi awal kemampuan interaksi sosial anak autis, proses bimbingan dan hasil bimbingan yang dilakukan oleh SLB Bunda Bening dengan metode Applied Behavior Analysis. Metode penelitian yang digunakan dalam penelitian ini yaitu deskriptif dengan jenis penelitian kualitatif. Penelitian kualitataif yaitu penelitian yang menggunakan katakata untuk mendeskripsikan hasil penelitiannya. Hal tersebut dibenarkan oleh pendapatnya Sukmadinata (2011: 73) yang mengatakan bahwa penelitian deskriptif kualitatif adalah metode penelitian yang digunakan untuk mendeskripsikan fenomena-fenomena yang sifatnya alamiah maupun rekayasa manusia. Adapun hal-hal yang dideskripsikan pada penelitian yaitu kondisi awal kemampuan interaksi sosial anak autis, proses pelaksanaan dan hasil dari bimbingan dengan metode terapi Applied Behavior Analysis.

\section{LANDASAN TEORITIS}

Bimbingan dalam perspektif keagamaan atau Islami adalah upaya membantu individu belajar mengembangkan dan atau kembali kepada fitrah-iman dengan cara memberdayakan (empowering) potensi dirinya yang terkait dengan jasmani, rohani, nafs dan iman. Sehingga fitrah-fitrah yang ada pada individu tersebut berkembang dan berfungsi dengan baik dan benar dalam menjalankan kehidupannya sehari-hari. Begitupun bimbingan perspektif keagamaan/Islami ini merupakan proses pemberian bantuan terarah, kontinu dan sistematis kepada setiap individu agar ia dapat mengembangkan potensi atau fitrah beragama yang dimilikinya secara optimal dengan cara menginternalisasikan nilai-nilai yang terkandung di dalam Al-Qur'an dan hadist Rasulullah ke dalam dirinya, sehingga ia dapat menyesuaikan diri dengan lingkungan kehidupannya sesuai dengan tuntunan Al-Qur'an dan hadis (Dudy Imanuddin Effendi, dkk, 2019: 254).

Metode adalah cara yang dianggap tepat untuk digunakan dalam melakukan sesuatu. (Primary, 2005: 56). Applied Behavior Analiysis merupakan salah satu metode yang ditemukan oleh Ivar O. Lovaas. Ivar menyebutkan bahwa perilaku tertentu bisa dihilangkan apabila ia mendapatkan sesuatu yang tidak 
Pengembangan Interaksi Sosial Anak Autis melalui Terapi Applied Behavior Analysis menyenangkan secara terus-menerus pada saat melakukan perilaku tertentu itu. (Handoyo, 2008: 15).

Menurut Yuwono dalam Hardiani dan Rahmawati (2017) dasar dari metode ABA ini menggunakan pendekatan teori behavioral yaitu pada tahap awal menekannkan kepatuhan, keterampilan anak dalam meniru, dan membangun kontak mata. Konsep kepatuhan ini sangat penting agar mereka dapat mengubah perilaku sendiri menjadi perilaku yang lazim dan dapat melakukan interaksi sosial.

Interaksi sosial adalah proses komunikasi antar individu yang saling mempengaruhi dalam berpikir dan bertindak, sebab pada dasarnya manusia tidak akan pernah terhindar dari hubungan antar individu yang saling mempengaruhi. (Setiadi dkk, 2013: 95).

Chodijah mengemukakan bahwa interaksi sosial dikatakan telah terjadi jika telah memenuhi persyaratan berikut ini: 1) Adanya kontak sosial, baik kontak sosial antar individu, antar kelompok, maupun antara individu dengan kelompok, yang dilakukan secara langsung tatap muka, ataupun tidak langsung seperti melalui media komunikasi lainnya. Kontak sosial ini dikatakan positif jika melahirkan kerja sama, namun dikatakan negatif jika melahirkan permusuhan; 2) Adanya komunikasi sosial antar individu, antar kelompok maupun antara individu dengan kelompok. Artinya, pesan yang ingin disampaikan komunikator dapat diterima oleh lawan bicaranya. (Chodijah, 2017: 123).

IDEA (Idividuals with Disabilities Education Act Amandements) mengemukakan bahwa autis adalah gangguan perkembangan pada syaraf pusat yang menyebabkan ia memiliki hambatan dalam interaksi sosial, berkomunikasi dan berperilaku. (Destiningrum, 2016: 7).

Terkait penggunaan metode terapi Applied Behavior Analysis sebagai bentuk dari pengaplikasian teori behavioristik BF Skinner, Andriyani mengatakan bahwa teori belajar behavioristik seperti yang dianut oleh B.F. Skinner -orang yang teorinya diaplikasikan oleh Ivar O. Lovass- bukan hal yang baru dalam Islam. (Andriyani, 2015: 175). Sejak dahulu, teori ini pernah tersirat dalam hadits Rasulullah Saw (Ibnu Hajar Al-Asqolani, 1997: 406) berikut:

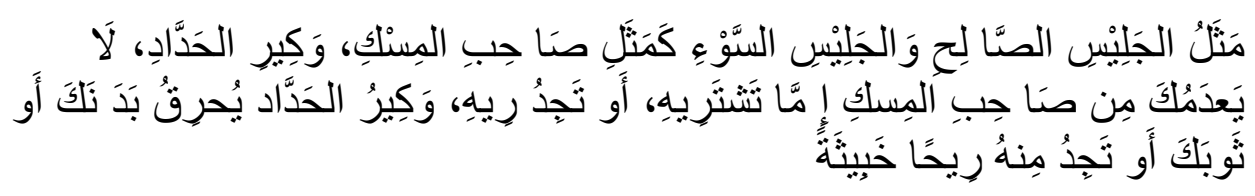

Artinya:

Perumpamaan teman yang baik dan teman yang buruk seperti pedagang minyak kasturi dan peniup api tukang besi. Si pedagang minyak kasturi mungkin akan memberinya kepadamu atau engkau membeli kepadanya atau setidaknya engkau dapat memperoleh bau yang harum darinya, tapi si peniup api tukang besi mungkin akan membuat badanmu atau pakaianmu 
terbakar atau mungkin engkau akan mendapat bau yang tidak sedap darinya. (HR. Bukhori 5534 \& Muslim 2628).

Berdasarkan hadits tersebut dapat disimpulkan bahwa lingkungan dapat mempengaruhi tabiat seseorang. Jika lingkungan yang dipijakinya baik, maka kepribadiannya pun akan mengikuti lingkungan yang dipijakinya tersebut.

Menilik pendapatnya Hamruni, imbalan ini dapat disamakan artinya dengan hadiah atau reinforcement dalam bahasanya Lovas. Adapun macam-macam hadiah menurut Hamruni yaitu: 1) Hadiah materi yaitu guru memberikan hadiah berupa sesuatu yang mengesankan kepada anak didiknya karena telah melakukan hal yang diperintahkan; 2) Hadiah dalam bentuk do'a yaitu guru memberikan hadiah dalam bentuk do'a agar anak selalu mendapatkan keberkahan hidupnya; 3) Hadiah pujian yaitu guru memberikan hadiah kepada anak didiknya berupa pujian atas pencapaiannya. (Hamruni, 2009: 242-243).

Dengan demikian dapat disimpulkan bahwa prinsip memberikan reinforcement/imbalan atas perilaku yang dilakukan seseorang termasuk anak autis, telah dilakukan Rasulullah kepada para sahabatnya sejak dahulu kala. Sinyal ini merupakan pijakan bagi para pembimbing dalam melakukan upaya pemberian bantuan kepada para terbimbing, termasuk anak-anak autis untuk meningkatkan potensinya dalam melakukan penyesuaian diri dengan lingkunganya

\section{HASIL DAN PEMBAHASAN}

SLB Autisma Bunda Bening Selakshahati terletak di Kampung Cibirubeet Hilir RT 05 RW 13, Desa Cileunyi Wetan, Kecamatan Cileunyi, Kabupaten Bandung, Provinsi Jawa Barat, mulanya yaitu pusat terapi untuk anak autism yang didirikan pada tahun 2001 di Kampung Parakanmuncang Blok. A.2 No. 59 Desa Cihanjuang, Kecamatan Parakanmuncang, Kabupaten Sumedang. Kemudian dari sana banyak ditemukan anak-anak pada fase remaja dan dewasa yang mengalami regresi. Setelah itu pada tahun 2010, Bunda memutuskan untuk mengasuh anak selama 24 jam untuk mengetahui penyebab regresi tersebut. Setelah memutuskan untuk mengasuh anak autis selama 24 jam, Bunda pun mengetahui tahapan yang harus dilakukan untuk menangani anak yang mengalami regresi (penurunan kemampuan).

Kejadian tersebut otomatis membuat Bunda dan pengurus lainnya berpikir "Anak-anak ini pun berhak mendapatkan pendidikan yang layak sebagaimana anak biasa lainnya". Maka, pada tahun 2014 Bunda dan pengurus lainnya mengajukan izin operasional ke disdik (Dinas Pendidikan) dan pada akhirnya banyak pihak yang mendukung. Kemudian pada tahun 2016 SLB Autisma Bunda Bening Selakshahati mendapatkan izin operasional. 
Pengembangan Interaksi Sosial Anak Autis melalui Terapi Applied Behavior Analysis Jumlah Siswa SLB Autisma Bunda Bening Selakshahati

Tahun Ajaran 2019-2020

Tabel 3.1 Jumlah Siswa SLB Autisma Bunda Bening Selakshahati

\begin{tabular}{lll}
\hline NO & Satuan Pendidikan & Jumlah Anak \\
\hline 1 & SDLB & 19 \\
2 & SMPLB & 17 \\
3 & SMALB & 40 \\
\hline
\end{tabular}

Sumber: Arsip Dokumen SLB Autisma Bunda Bening Selakshahati

Klien yang menjadi subyek penelitian ini yaitu anak autis usia Sekolah Dasar Luar Biasa yang bernama Rakha Gibran Pratama dan anak usia Sekolah menengah Atas Luar Biasa/Kelas Vokasional yang bernama Fadil.

\section{Kondisi Awal Kemampuan Interaksi Sosial Anak Autis}

Berdasarkan hasil penelitian, dapat dideskripsikan bahwa anak autis ialah anak berkebutuhan khusus yang memiliki hambatan-hambatan dalam berkomunikasi, berbahasa, berperilaku dan melakukan interaksi sosial. Seperti yang dapat dilihat dari kondisi awal interaksi sosial anak autis saat masuk ke SLB Autisma Bunda Bening Selakshahati.

Hal ini sesuai dengan pernyataan IDEA (Idividuals with Disabilities Education Act Amandements) mengemukakan bahwa autis adalah gangguan perkembangan pada syaraf pusat yang menyebabkan ia memiliki hambatan dalam interaksi sosial, berkomunikasi dan berperilaku. (Destiningrum, 2016: 7).

Adapun hasil wawancara dengan Bunda, dapat diketahui bahwa kondisi awal interaksi sosial setiap anak autis yang baru masuk ke SLB Autisma Bunda Bening Selakshahati, biasanya mereka belum bisa berinteraksi sosial dengan bagus. Artinya, anak autis yang baru masuk biasanya belum memiliki kontak mata yang bagus, tidak lancar dalam menggunakan bahasa verbal, tidak mau disentuh, tidak bisa mengatakan apa yang dia inginkan dan tidak bisa pula mengatakan hal yang tidak dia inginkan. (Wawancara dengan Bunda, 10 Maret 2020).

Kondisi awal kemampuan interaksi sosial anak autis tersebut menunjukkan bahwa anak autis yang pertama kali masuk ke SLB Autisma Bunda Bening memiliki hambatan kualitatif dalam interaksi sosial. Hambatan dalam melakukan interaksi sosial yang dialami anak autis ini, diklasifikasikan menjadi tiga kelompok oleh Hadis, yaitu: 1) Kelompok aloof atau kelompok anak autis yang cenderung menutup diri, tidak mau berinteraksi dengan orang lain dan tidak suka jika ada yang mendekati. Anak autis pada kelompok ini mempunyai kesulitan dalam meniru gerakan bermakna, seperti melambaikan tangan dan menganggukkan 
A, Siti., E, Marlina., D, EI, Effendy.

kepala; Kedua kelompok pasif atau kelompok yang dapat menerima pendekatan sosial dan dapat mengikuti permainan bersama, jika permainan tersebut disesuaikan dengan keinginan dirinya. Meskipun anak autis pada kelompok ini bisa diajak bermain bersama, namun permainanya itu tanpa imajinasi, berulang dan terbatas; Ketiga kelompok aktif tapi aneh atau kelompok yang berperilaku tidak sewajarnya orang normal, memilki kemampuan verbal yang lebih baik jika dibandingkan dengan kedua kelompok sebelumnya. Sebab, biasanya hambatan sosial anak autis akan semakin berkurang seiring dengan bertambahnya usia. (Hadis, 2006: 52).

Salah satu anak autis yang memiliki hambatan interkasi sosial pada saat baru masuk ke SLB Autisma Bunda Bening Selakshahti yaitu Rakha Gibran Pratama anak autis usia Sekolah Dasar Luar Biasa (SDLB)-. Menurut Bu Nita sebagai guru pengajarnya, kondisi Rakha saat pertama kali mengikuti pembelajaran di SLB Autisma Bunda Bening Selakshahati, dalam hubungannya dengan individu lain seperti melakukan interaksi sosial dengan gurunya, ia masih belum memiliki kontak mata yang bagus, bahasa verbalnya masih terbatas, tidak bisa membaca, tidak bisa menulis dan masih belum bilang kalau mau ke kamar mandi. Sedangkan dalam hubungannya dengan lingkungan, ia juga masih melakukan permainan repetitif (diulang-ulang) seperti pada saat ia ingin minum air. Ia akan meminta minum sampai berulang kali selagi masih diberi. (Hasil Observasi dan Wawancara dengan Bu Nita, 03 Maret 2020).

Berbeda dengan anak autis usia SDLB, anak autis usia kelas vokasional yang bernama Fadil. Menurut wa Iis, pertama kali Fadil masuk ke asrama Autisma Bunda Bening Selakshahati dalam hubungannya dengan individu lainnya yaitu adanya kemampuan anak dalam melakukan kontak mata, mampu melakukan komunikasi dua arah, mampu menyampaikan hal-hal yang dia butuhkan dan inginkan. Namun, dalam hubungannya dengan lingkungan ia tidak menghendaki adanya perubahan-perubahan sehingga ia akan marah jika terjadi perubahan, menunjukkan permainan yang repetitif (diulang-ulang) seperti akan mengatakan "aw sakit" pada saat menyentuh air dan akan berjalan, serta cenderung menggunakan tangan orang dewasa sebagai alat bantu ia berjalan. (Wawancara dengan wa Iis Mintarsih, 10 Maret 2020).

Perilaku Rakha Gibran Pratama dan Fadil ini sesuai dengan karakteristik anak autis yang dikemukakan oleh Handoyo berikut: 1) Bahasa atau komunikasi, dalam hal ini anak menunjukkan bahwa anak autis tidak memiliki ekspresi wajah seperti orang pada umumnya, tidak memahami bahasa tubuh, tidak banyak berbicara dan bahasa verbalnya pun terbatas; 2) Hubungan dengan orang, dalam hal ini anak menunjukkan perilaku yang tidak responsif saat berinteraksi sosial dengan orang lain, tidak sering bahkan nyaris tidak mampu melakukan kontak mata dengan orang lain, dan menggunakan tangan orang dewasa sebagai alat; 3) Hubungan dengan lingkungan, dalam hal ini anak menunjukkan permain repetitif, 
Pengembangan Interaksi Sosial Anak Autis melalui Terapi Applied Behavior Analysis marah atau tidak menyukai perubahan-perubahan yang tidak sesuai dengan keinginannya, dan memperlihatkan ketertarikan yang sangat tak fleksibel; 4) Respon terhadap indera atau sensoris, dalam hal ini anak menunjukkan perilaku yang sangat sensitif terhadap suara, menarik diri ketika disentuh, sangat hiperaktif;

5) Kesenjangan perkembangan perilaku, dalam hal ini perilaku anak menunjukkan bahwa ia memiliki kemampuan yang sangat baik dalam satu hal namun sangat terlambat dalam hal lainnya, seperti dalam hal membaca ia mampu namun tak paham maksudnya; ia dapat menggambar secara rinci tapi tidak dapat pandai dalam mengancingkan baju; ia pandai menyusun puzzle tapi kesulitan mengikuti perintah; ia mampu berjalan pada usia normal namun tidak berkomunikasi; ia lancar membeo suara namun kesulitan untuk berbicara menyampaikan keinginannya sendiri; pada suatu waktu ia bisajadi dapat melakukan sesuatu tapi tidak di lain waktu. (Handoyo, 2004: 24).

Oleh sebab itu, berdasarkan pemaparan di atas peneliti menyimpulkan bahwa kondisi awal interaksi sosial anak autis yang ada di SLB Autisma Bunda Bening Selakshahati sesuai dengan teori di atas, yaitu mengalami hambatan dalam melakukan interaksi sosial baik dalam hubungannya dengan individu lainnya seperti tidak melakukan kontak mata saat berinteraksi sosial, tidak responsif dan menggunakan tangan orang dewasa sebagai alat bantunya, dan dalam hubungannya dengan lingkungan pun mengalami hambatan seperti adanya perilaku yang repetitif (diulang-ulang) serta tidak menyukai perubahan-perubahan.

\section{Proses Pelaksanaan Bimbingan Dengan Metode Terapi Applied Behavior Analysis}

Menurut Chodijah, secara Islami bimbingan ini ditujukan kepada setiap individu baik anak-anak maupun dewasa, bermasalah ataupun tidak; Bimbingan dilakukan untuk membantu konseli mengembangkan potensi yang dimilikinya dengan maksimal; Kegiatan bimbingan ini memiliki tujuan membantu individu agar dapat menyesuaikan dirinya dengan lingkungan. (Chodijah, 2017: 16).

Dengan demkikian, anak berkebutuhan khusus autis pun termasuk ke dalam individu yang membutuhkan bimbingan secara Islami untuk mengembangkan potensi yang ia miliki dan dapat menyesuaikan dirinya dengan lingkungannya, hingga lebih jauhnya dapat mengenalkannya pada syariat Islam. Hanya saja, metode yang harus digunakan untuk membantu anak berkebutuhan khusus autis, tidak bisa disamakan dengan metode-meode bimbingan yang biasa digunakan untuk membantu anak normal pada umumnya.

Salah satu metode bimbingan yang dapat digunakan untuk membantu anak berkebutuhan khusus autis dalam mengembangkan kemampuan interaksi sosialnya, yaitu bimbingan dengan metode terapi Applied Behavior Analysis. Secara teori metode terapi Applied Behavior Analysis memiliki prinsip-prinsip berikut: penyampainnya dilakukan dengan mengedepankan rasa kasih sayang dan kehangatan; pelaksanaanya tidak dengan marah-marah; metode ini dilakukan 
A, Siti., E, Marlina., D, EI, Effendy.

dengan tegas dan konsisten; metode ini membantu anak untuk tetap menjaga kontak mata; serta memberikan imbalan pada anak sebagai apresiasi atas pencapaiannya. (Ardianingsih, 2017: 3).

Berkaitan dengan pemaparan di atas, fakta di lapangan pun menunjukkan hal yang sama. Setiap terapis, konselor, guru, staff dan pengasuh melakukan bimbingan dengan metode terapi Applied Behavior Analysis dengan mengedepankan rasa kasih sayang dan kehangatan; namun tetap konsisten dan tegas dalam memberikan instruksi serta tidak lupa selalu memberikan imbalan, baik dalam bentuk materil maupun moril sebagai apresiasi atas pencapaian perilaku yang dilakukan anak autis. Seperti yang dilakukan wa Iis Mintarsih selaku pengasuh asrama kepada Bang Fadil pada saat ia sudah bisa berjalan dengan lancar dan sudah mau mandi kembali, wa Iis Mintarsih mengatakan: "Tub abang bisa jalan. Ya emang abang gak sakit, abang mah kan sehat.". Menurut wa Iis dalam wawancara (10 Maret 2020), setelah dipuji dengan perkataan itu bersangsur-angsur Bang Fadil jadi mau terus berjalan seperti biasanya.

Adapun dalam proses pelaksanaan bimbingan dengan metode terapi Applied Behavior Analysis yang dilakukan di SLB Autisma Bunda Bening Selakshahati, baru dapat dilaksanakan setelah memenuhi unsur-unsur bimbingan. Menurut Wulandari (2014: 37-40) yang termasuk ke dalam unsur-unsur bimbingan yaitu sebagai berikut: 1) Pembimbing, yaitu orang yang membantu klien dalam mengatasi masalah yang dimilikinya. Adapun orang yang berperan sebagai pembimbing di SLB Autisma Bunda Bening Selakshahati yaitu konselor, terapis, guru, staff dan pengasuh. Bedanya, jika terapis lebih banyak melakukan layanan kepada anak autis usia Sekolah Dasar Luar Biasa (SDLB) sebab menurut Bunda Bening, anak kecil itu masih membutuhkan penanganan yang ekstra dalam artian pelaksanaannya harus dilakukan di dalam ruangan agar fokus anak tidak hilang. (Wawancara dengan Bunda, 10 Maret 2020). Adapun pelaksanaan bimbingan pada anak autis usia kelas vokasional dapat dilakukan di mana pun, seperti di dapur ataupun di Kasur. Pernyataan Bunda tersebut dibenarkan adanya oleh pakar ABA yang sudah mendapatkan sertifikat dari BCBA (Behavior Analyst Certification Board-Badan Berpusat di Amerika yang mengakreditasi profesi behavior analyst dunia) bernama Ms. Meera Ramani yang mengatakan bahwa:

Program ABA bisa saja dapat anda lakukan di meja, anda juga dapat melakukannya di luar meja atau keduanya. Anda juga dapat melakukannya di taman bermain, di dalam kelas, di dalam mall atau kemanapun anda pergi. (Soeriawinata, www.rurysoeriawinata.com, akses 25 Februari 2018).

Dengan demikian, dapat disimpulkan bahwa orang yang bisa melakukan bimbingan dengan metode terapi Applied Behavior Anlysis tidak hanya orang yang sudah mempunyai sertifikat saja, sebab metode terapi Applied Behvaior Analysis yang dilakukan selama 24 jam di SLB Autisma Bunda Bening Selakshahati 
Pengembangan Interaksi Sosial Anak Autis melalui Terapi Applied Behavior Analysis ini dijadikan salah satu metode yang tepat untuk membimbing anak autis dalam kehidupan sehari-hari dan bisa dilakukan dimana pun seperti yang dikemukan oleh pakar ABA Ms. Meera Ramani; 2) Klien, yaitu orang yang diberikan bantuan oleh pembimbing, sekaligus orang yang meminta bantuan pembimbing untuk mengatasi masalah yang dimilikinya. Adapun klien yang mendapatkan bimbingan yaitu seluruh anak autis mulai dari anak autis usia Sekolah Dasar Luar Biasa, Sekolah Menengah Pertama Luar Biasa, Sekolah Menengah Atas Luar Biasa dan usia kelas vokasional. Klien yang menjadi subyek penelitian ini yaitu anak autis usia Sekolah Dasar Luar Biasa dan kelas vokasional saja; 3) Masalah, yaitu suatu kondisi yang tidak sesuai antara harapan dengan kenyataan. Masalah yang dimiliki anak autis yaitu memiliki hambatan dalam berperilaku, berbahasa dan berinteraksi sosial.

Setelah unsur-unsur tersebut ada semuanya, sebuah proses tentu membutuhkan langkah-langkah agar tujuan dapat tercapai, demikian juga dengan bimbingan dengan metode terapi Applied Behavior Analysis ini. Langkah-langkah bimbingan menurut Salahudin (2010: 95-96) yaitu: 1) Identifikasi masalah, hal ini dilakukan untuk mengetahui siapa saja anak yang membutuhkan bimbingan dan untuk mengetahui apa saja yang dibutuhkan oleh anak. Pada langkah ini sebagai seorang terapis yang melakukan bimbingan dengan metode terapi Applied Behavior Analysis kepada anak autis usia Sekolah Dasar Luar Biasa (SDLB), terapis melakukan assesmen terlebih dahulu untuk menentukan program yang tepat untuk anak autis.

Biasanya assesmen ini dilakukan oleh terapis itu sendiri dan dilakukan secara terus-menerus, bahkan pada saat melakukan bimbingan dengan metode terapi Applied Behavior Analysis pun asessmen ini tetapi dilakukan, mengingat perilakuperilaku baru anak bisa saja muncul kapanpun. Perilaku anak yang muncul pada saat pelaksanaan bimbingan dengan metode terapi Applied Behavior Analysis kemudian dicatat, lalu dikumpulkan dan dibuat kembali program yang tepat untuk membantu perkembangan anak tersebut, ada program jangka pendek dan ada pula program jangka panjang.

Pelaksanaan program bimbingan ini biasa dilakukan mulai dari program yang dianggap urgent terlebih dahulu. Adapun langkah yang dilakukan oleh konselor untuk mengetahui apa yang dibutuhkan anak, yaitu menanyakan langsung kepada pengasuh asrama sebagai orang yang selalu menemani anak autis selama 24 jam penuh; 2) Dignosis, yaitu langkah untuk menetapkan hal apa yang menjadi masalah bagi anak beserta latarbelakangnya. Pada langkah ini terapis dan konselor sama-sama mengamati anak autis secara langsung untuk mengetahui halhal yang menjadi masalah bagi anak autis; 3) Prognosis, yaitu langkah-langkah yang dilakukan untuk menetapkan jenis bantuan yang tepat untuk diberikan pada anak. Pada langkah ini terapis menetapkan sendiri jenis bantuan yang harus diberikan kepada anak autis dengan mempertimbangkan hasil assesmen, sedangkan 
A, Siti., E, Marlina., D, EI, Effendy.

konselor menetapkan pemberian bantuan pada anak autis ini dengan mendiskusikannya dengan pengasuh asramanya; 4) Terapi, langkah terapi yaitu langkah pelaksanaan bimbingan atau pemberian bantuan pada anak. Pada langkah ini terapis dan konselor tentu saja memberikan terapi sesuai dengan yang dibutuhkan oleh anak autis. Namun, jika yang dibutuhkan oleh anak autis itu kemampuan interaksi sosial maka salah satu cara yang dilakukan terapis dan konselor untuk membantunya yaitu memberikan bimbingan dengan metode terapi Applied Behavior Analysis.

Pelaksanaan bimbingan yang diberikan terapis kepada anak autis usia SDLB dilakukan dengan posisi terapis di depan anak, anak di tengah dan co-terapis berada di belakang anak autis. Pada saat anak masuk ruangan, anak kemudian diarahkan untuk duduk jika anak tidak duduk juga maka dilakukan promt (menyuruh anak untuk duduk namun tidak diucapkan secara verbal). SLB Autisma Bunda Bening Selakshahati selalu menyisipkan nilai-nilai Islami ke dalam setiap programnya, termasuk pada saat pelaksanaan bimbingan dengan metode terapi Applied Behavior Analysis. Proses pelakasanaan bimbingan dengan metode terapi Applied Behavior Analysis ini dimulai dengan mengucapkan do'a dan membaca surat-surat pendek seperti surat An-Nas, Al-Falaq dan Al-Ikhlas, yang kemudian layanan ini diakhiri dengan membacakan sholawat bersama-sama.

Instruksi yang diberikan pada saat pelaksanaan bimbingan dengan metode terapi Applied Behavior Analysis hendaknya diawali dengan membuat kontak mata anak fokus terlebih dahulu. Gunakan kata-kata yang baku dan tidak bertele-tele saat memberikan instruksi. Jika menyuruh untuk duduk maka katakana "Duduk!" jika anak tidak merespon maka lakukan promt. Berbeda dengan sebelumnya, bimbingan dengan metode terapi Applied Behavior Analysis yang diberikan pada anak autis usia kelas vokasional ini sifatnya kondisional. Jika ada masalah, baru konselor menangani permasalahan tersebut. Adapun tahapan-tahapannya yaitu sebagai berikut: a) Cari tahu terlebih dahulu kronologis dan penyebab kasus tersebut terjadi, b) Konselor mendiskusikan terlebih dahulu cara yang terbaik untuk menangani setiap kasus anak autis usia remaja dan dewasa, c) Kasus tersebut bisa saja ditangani oleh konselor atau pengasuh asrama, keempat barulah kasus ditangani sesuai kronologisnya. Penanganan terhadap anak autis ini tidak bisa disamaratakan, meskipun mereka sama-sama autis namun tidak bisa disamakan. Otomatis penangannya pun disesuaikan dengan kebutuhan dan kasusnya; 5) Evaluasi atau follow up, pada langkah ini dilakukan evaluasi atau penilaian atas hasil yang bisa dicapai melalui pemberian terapi tersebut. Pada langkah ini terapis dan konselor mengamati secara terus menerus perkembangan anak autis untuk menilai sejauh mana pencapaiannya.

Berdasarkan pemaparan di atas, dapat disimpulkan bahwa proses bimbingan dengan metode terapi Applied Behavior Analysis yang dilakukan di SLB Autisma Bunda Bening Selakshahati, berdasarkan teori langkah-langkah 
bimbingan.

\section{Hasil Bimbingan Dengan Metode Terapi Applied Behavior Analysis}

Metode terapi Applied Behavior Analysis dianggap sebagai salah satu cara yang representatif untuk menanggulangi permasalahan penyimpangan perkembangan anak autis (Kingley, 2006: 8). Dikatakan representatif disebabkan oleh sifatnya yang sistematis dan terarah.

Hal tersebut sesuai dengan fakta dilapangan yang menunjukkan bahwa, anak autis SLB Autisma Bunda Bening Selakshahati yang mendapatkan layanan bimbingan dengan metode terapi Appliede Behavior Anlysis dalam kehidupannya sehari-hari mengalami perkembangan yang begitu pesat khususnya dalam kemampuan interaksi sosialnya.

Berdasarkan hasil observasi dan wawancara dengan Bu Nita dapat diketahui bahwa anak autis usia Sekolah Dasar Luar Biasa (SDLB) yang bernama Rakha Gibran Pratama sudah bisa mengeluarkan bahasa verbal, memiliki kontak mata yang bagus, sudah bisa mengatakan apa yang dia inginkan. Misalnya, saat dia ingin pergi ke kamar mandi ia akan bilang "Pi pi pipis" dan saat dia ingin minum maka ia akan mengatakan "Minum minum". Meskipun pada saat dia pergi ke kamar mandi, ia masih minta diantar dan pada saat dia minum, gelasnya masih suka dimainkan. Tidak hanya itu, dalam hubungannya dengan individu lain Rakha Gibran Pratama juga sudah bisa melakukannya dengan baik seperti memberi salam pada peneliti saat melakukan observasi. (Observasi dan Wawancara dengan Bu Nita, 03 Maret 2020). Kejadian tersebut dapat dilihat pada gambar di bawah ini:

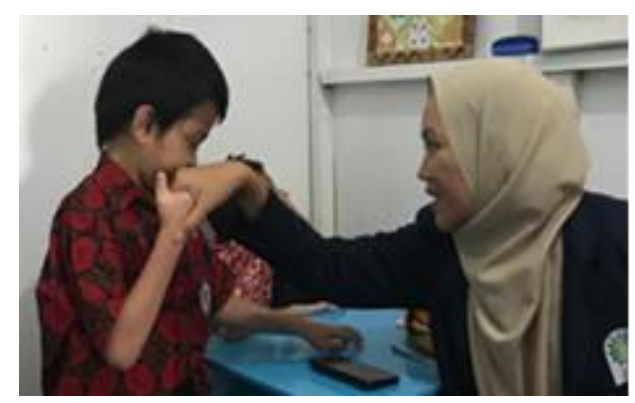

Sumber: Dokumentasi Observasi 03 Maret 2020

Gambar 3.1 Rakha Mau dan Bisa Bersalaman dengan Orang Baru

Hal ini terjadi sebagai hasil dari perilaku yang diinstruksikan dilakukan secara berulang-ulang dan terus menerus dengan sikap tegas dan konsisten yang diterapkan dalam bimbingan dengan metode terapi Applied Behavior Analysis.

Jika dibandingan dengan Rakha, Fadil -anak autis usia kelas vokasionaljustru terlihat memiliki kemampuan interaksi sosial yang lebih bagus. Pasalnya, 
A, Siti., E, Marlina., D, EI, Effendy.

Fadil ini sudah bisa mengatakan hal yang dinginkannya; sudah bisa mengatakan hal yang tidak diinginkannya; sudah mampu membedakan ciri-ciri seseorang, misalnya membedakan antara bayi dan orang dewasa; dan sudah bisa berkomunikasi dua arah. Di samping karena faktor usia, yang menyebabkan hambatan sosialnya semakin berkurang seperti yang dikatakan Hadis (2016: 52), hal ini juga terjadi sebagai akibat dari hasil bimbingan wa Iis selaku pengasuh asramanya yang menerapkan bimbingan sesuai dengan arahan Bunda Bening selaku konselor yaitu dengan memberikan instruksi yang tegas, konsisten dan selalu memberikan apresiasi atas pencapaiannya selama 3-4 bulan.

Hal ini dapat diketahui melalui video dokumentasi SLB Autisma Bunda Bening Selakshahti yang diperlihatkan wa Iis pada saat wawancara. Di dalam arsip video tersebut menunjukkan bahwa Fadil merasa kesulitan untuk berjalan, namun pengasuhnya dengan tegas mengatakan "Ayo Bang Fadil jalan, Bang Fadil bisa", dengan tetap mengatakan "Aw sakit” Bang Fadil terus berjalan dari kamar mandi menuju kamar tidurnya. Melihat kondisi Bang Fadil yang mau terus berjalan, pengasuhnya lalu mengatakan "Bang Fadil pinter" sebagai bentuk apresiasi atas perilakunya. Kemudian Bang Fadil mengatakan "Iya, pinter" dan mau melanjutkan jalannya seperti orang biasa pada umumnya. (Wawancara dengan Wa Iis, 10 Maret 2020). Kejadian tersebut dapat dilihat pada gambar di bawah ini:

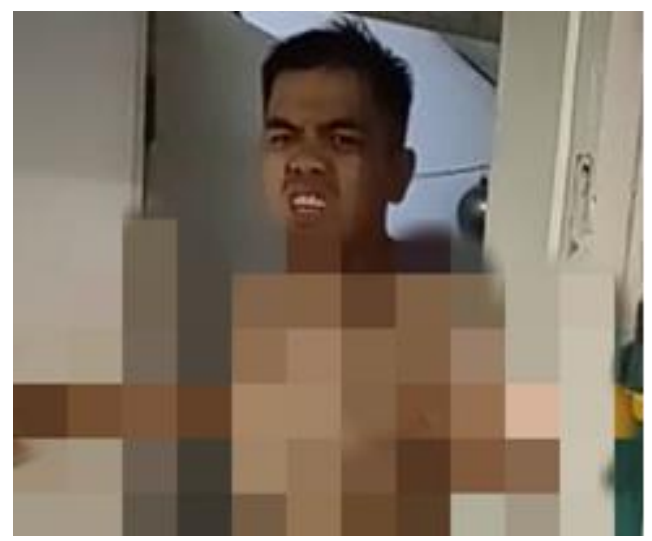

Sumber: Arsip SLB Autisma Bunda Bening Selakshahati

Gambar 3.2 Fadil Mulai Mau Berjalan Kembali Tanpa Bantuan Orang Dewasa.

Perilaku Rakha dan Fadil di atas telah memenuhi salah satu syarat terjadinya interaksi sosial seperti yang dikemukakan Chodijah (2017: 123) berikut ini:

Adanya kontak sosial, hal ini berlangsung dalam tiga bentuk interaksi sosial yakni interaksi individu dengan individu, individu dengan kelompok dan kelompok dengan kelompok. Suatu kontak sosial ini dapat bersifat langsung (bertemu secara langsung) maupun tidak langsung seperti melalui telepon, 
Pengembangan Interaksi Sosial Anak Autis melalui Terapi Applied Behavior Analysis surat dan yang lainnya. Kontak sosial ini pun dapat bersifat positif yang menghasilkan kerja sama antar individu, antar kelompok dan antara individu dengan kelompok. Selain itu, kontak sosial ini pun dapat bersifat negatif yang melahirkan pertentangan. Meskipun fakta di lapangan menunjukkan bahwa anak autis ini baru bisa melakukan interaksi sosial antar individu saja, seperti melakukan interaksi sosial dengan konselor, terapis, guru dan pengasuh.

Dengan demikian, dapat disimpulkan bahwa bimbingan dengan metode terapi Applied Behavior Analysis yang memiliki konsep tegas, konsisten, penuh kehangatan dan selalu memberikan apresiasi atas perilaku anak baik berupa moril ataupun materil dalam bentuk imbalan ataupun hukuman mampu mengembangkan kemampuan interaksi sosial anak autis.

\section{PENUTUP}

Berdasarkan hasil penelitian yang dilakukan oleh peneliti mengenai bimbingan dengan metode terapi Applied Behavior Analysis untuk mengembangkan kemampuan interaksi sosial anak autis di SLB Autisma Bunda Bening Selakshahati, maka dapat ditarik kesimpulan sebagai berikut:

Pertama, Kondisi awal kemampuan interaksi sosial anak autis SLB Autisma Bunda Bening Selakshahati yang menjadi subyek penelitian anak autis usia Sekolah Dasar Luar Biasa (SDLB) yang bernama Rakha Gibran Pratama dan anak autis usia Sekolah Menengah Atas Luas Biasa/Kelas Vokasional yang bernama Fadil, masih belum memiliki kontak mata yang bagus dan memiliki bahasa verbal yang terbatas, masih melakukan permainan repetitive, tidak menghendaki adanya perubahan-perubahan sehingga ia akan marah jika terjadi perubahan dan cenderung menggunakan tangan orang dewasa sebagai alat bantunya.

Kedua, Proses pelaksanaan bimbingan dengan metode terapi Applied Behavior Analysis yang dilakukan di SLB Autisma Bunda Bening Selakshahati dengan konsep tegas, konsisten, penuh kehangatan dan selalu memberikan apresiasi atas perilaku anak baik berupa moril ataupun materil dalam bentuk imbalan ataupun hukuman. Pelaksanaan bimbingan dengan metode terapi Applied Behavior Analysis yang diberikan kepada anak autis usia SDLB yang bernama Rakha Gibran Pratama dilakukan oleh terapis, dilakukan di dalam ruangan, dilakukan rutin pada hari tertentu dan teknisnya dimulai dengan dilakukan assesmen terlebih dahulu kemudian bimbingan dilakukan sesuai prosedur metode terapi Applied Behavior Analysis. Sedangkan anak autis usia kelas vokasional yang bernama Fadil dilakukan oleh konselor, dilakukan di manapun, dilakukan pada saat ada kasus berat dan prosesnya dimulai dengan mencari tahu kronologis masalahnya, mendiskusikan cara menanganinya lalu melakukan bimbingan secara langsung dan melakukan evaluasi. 
A, Siti., E, Marlina., D, EI, Effendy.

Ketiga, Hasil bimbingan dengan metode terapi Applied Behavior Analysi anak autis sudah bisa melakukan kontak mata yang bagus, bisa mengeluarkan bahasa verbal, bisa mengatakan apa yang dia inginkan, bisa mengatakan hal yang tidak diinginkannya, bisa membedakan ciri-ciri seseorang dan sudah bisa berkomunikasi dua arah.

\section{DAFTAR PUSTAKA}

Andriyani, F. (2015). Teori Belajar Behavioristik Dan Pandangan Islam Tentang Behavioristik: Syaikhuna Edisi 10 Nomor 2, 175.

Ardianingsih, T. S. (2017). Pelaksanaan Metode Applied Behavior Analysis Dalam Peningkatan Kemampuan Komunikasi Reseptif Anak Autis di Lembaga Terapi: Jurnal Pendidikan Khusus, 2.

Asrizal. (2016). Penanganan Anak Autis dalam Interaksi Sosial dalam Jurnal PKS 15 (1), 1-8.

Astuti, Diah. (2014). Perilaku Anak Berkebutuhan Khusus Gangguan Autisme di SLB Negeri Semarang dalam Jurnal Unnes: Early Childhood Education Paper (BELIA) 3 (2), 72 -78.

Chodijah, S. (2017). Psikologi Bimbingan Dan Konseling. Jakarta Timur: Cakrawala Budaya.

Desiningrum, D. R. (2016). Psikologi Anak Berkebutuban Khusus. Yogyakarta: Psikosain.

Effendi, Dudy Imanuddin, dkk. (2019). Peran Bimbingan Keagamaan Dalam Meningkatkan Kecerdasan Spiritual, Jurusan Bimbingan dan Konseling Islam Fakultas Dakwah dan komunikasi Universitas Islam Negeri Sunan Gunung Djati Bandung: Jurnal IRSYAD No.7 (2).

Fani, Muhamad. (2018). Pujian Rasulullab Terhadap Umar bin Khatab, diakses 11 September 2018, dari www.islami.co.

Hadis, A. (2006). Pendidikan Anak Berkebutuban Khusus-Autistik. Bandung: Alfabeta.

Hamruni. (2009). Strategi dan Model-model Pembelajaran Aktif Menyenangkan.

Yogyakarta: Fakultas Tarbiyah UIN Sunan Kalijaga.

Handoyo, Y. (2008). Autisma. Jakarta: Bhuana Ilmu Populer.

Kemenpppa. (2018). Hari Peduli Autisme Sedunia Kenali Gejalannya Pahami

Keadaannya, diakses 02 April 2018, dari www.kemenpppa.go.id.

Kingley, J. (2006). Applied Behavior Analysis. Jakarta: Gramedia.

Ormrod, J. E. (2008). Psikologi Pendidikan Jilid I. Jakarta: Erlangga.

Salahudin, A. (2010). Bimbingan dan Konseling. Bandung: Pustaka Setia.

Sartika. (2019). Teknik ABA sebagai sarana komunikasi Interpersonal antara ibu dan anak penyandang Autisme di PLA (Pusat layanan Autis) Riau dalam Jurnal Communiverse 4 (2), 30 - 40

Setiadi E. M, Hakam KA \& Effendi R. (2013). Ilmu Sosial Budaya Dasar. Jakarta: 
Kencana.

Pengembangan Interaksi Sosial Anak Autis melalui Terapi Applied Behavior Analysis

Soeriawinata, Rury. (2020). Meet The ABA Expert, diakses 25 Februari 2018, dari www.rurysoeriawinata.com.

Sukmadinata, N. S. (2011). Metode Penelitian Pendidikan. Bandung: Remaja Rosdakarya.

Umar, Hisyam. (2014). 13. Ar-Rad: 11, diakses 2014, dari www.sayahafiz.com

Wulandari, T. A. (2014). Bimbingan dan Konseling Islam dengan Terapi Realitas Untuk Menangani Seorang Ibu yang Memiliki Anak Penyandang Autis di Gang Salafiyah Wonocolo Surabaya. Skripsi. Program Studi Bimbingan dan Konseling Islam. Universitas Islam Negeri Sunan Ampel. Surabaya. 
A, Siti., E, Marlina., D, EI, Effendy. 